\title{
A blend of plant proteins as a potential fishmeal substitute in the diet of Asian seabass Lates calcarifer (Bloch, 1790): Effect on growth, digestive enzymes and fatty acid composition
}

\author{
E. P. MADHUBABU, R. JANNATHULLA, H. IMRAN KHAN, K. AMBASANKAR \\ AND J. SYAMA DAYAL \\ ICAR-Central Institute of Brackishwater Aquaculture, 75, Santhome High Road, RA Puram, Chennai - 600028 \\ Tamil Nadu, India \\ e-mailsyamdayal@rediffmail.com
}

\begin{abstract}
A blend of plant proteins (soybean meal, groundnut oil cake, sunflower oil cake, wheat gluten meal and corn gluten meal at 4:2:1:6.5:6.5) was used to substitute fishmeal in the diet of Asian seabass Lates calcarifer (Bloch, 1790). Five iso-nitrogenous (401.13-407.33 $\mathrm{g} \mathrm{kg}^{-1}$ ) diets were prepared by substituting fishmeal at 0 (control), 25, 50, 75 and $100 \%$ (FM-R0, FM-R25, FM-R50, FM-R75 and FM-R100, respectively) using the above mix. Average final weight of the fish increased $(\mathrm{p}<0.05)$ by three-folds $(20.77-29.99 \mathrm{~g})$ after 45 days compared to their initial weight $(6.09 \pm 0.25 \mathrm{~g})$ in all the treatments, however, significant $(p<0.05)$ variation was observed between the dietary treatments $(p \leq 0.002)$. The results indicated that $50 \%$ of dietary fishmeal can be substituted and beyond this level resulted in significant reduction of growth performance. Broken-line analysis indicated optimal fishmeal substitution as $46.7 \%$. The highest activity of pepsin, trypsin, chymotrypsin, carboxypeptidases-A and B was observed in fish fed with diets FM-R0, FM-R25 and FM-R50. Dietary change significantly $(\mathrm{p}<0.05)$ influenced the carcass lipid composition of Asian seabass $(\mathrm{p} \leq 0.001)$. Fatty acids like $\mathrm{C} 20: 4, \mathrm{C} 20: 5$ and $\mathrm{C} 22: 6$ were significantly $(\mathrm{p}<0.05)$ low in fish carcass fed with higher levels of plant proteins (FM-R75 and FM-R100). The results concluded that dietary fishmeal level can be partially substituted using a blend of plant proteins in the diet of Asian seabass juveniles.
\end{abstract}

Keywords: Asian seabass, Digestive enzymes, Fatty acid, Fishmeal, Growth, Plant proteins

\section{Introduction}

Asian seabass Lates calcarifer (Bloch, 1790) is an economically important food fish and is generally cultured in tropical and subtropical regions of the Pacific and Indian Ocean and South-East Asian countries. In general, most marine carnivorous fish, including seabass require high dietary protein compared to omnivorous and herbivorous species. Therefore, fishmeal is being used as a major protein source in commercial formulations due to its balanced nutrients, in particular essential amino acids and fatty acids, higher palatability and digestibility (Jannathulla et al., 2019a). However, the global fishmeal production has reduced from 6.2 million t to 4.3 million $t$, in the past two decades due to various climatic events, which resulted in the escalation of its price from 452 to 2169 USD per ton (Jannathulla et al., 2019b; USDA, 2020). This scenario prompted researchers towards substituting a considerable quantity of fishmeal by using a potential alternative from various animal and plant origins. Though animal proteins have been extensively evaluated as a protein source in fish feeds, their utility has not been explored commercially due to the higher content of lipid and ash, which negatively influences the palatability and digestibility (Nandakumar et al., 2013). Besides, European Community stated that the usage of rendered animal protein sources, in particular meat and bone meal have been restricted in various countries due to the spread of Bovine Spongiform Encephalitis (Title 21 Part 589.2000 of the US Food and Drug Administration, Code of Federal Regulations). Therefore, researchers prefer plant protein sources as an alternative to fishmeal due to wide availability, reasonable price and to a certain extent desirable nutrient content (Jannathulla et al., 2018a).

Plant protein constituents and their byproducts such as soybean meal (Tomas et al., 2009), groundnut meal (Sanchez-Lozano et al., 2011) and other oil seed meals/cakes (Martínez-Llorens et al., 2012) have been successfully substituted by dietary fishmeal from 12 to $40 \%$ in different aquatic species. Similarly, glutens, in particular wheat gluten meal and corn gluten meal have shown to be potential protein sources, containing 60 to $80 \%$ of crude protein, which is reported to be a vital alternative to fishmeal (Nandakumar et al., 2017). Major problems associated with plant proteins are deficiencies 
of certain essential amino acids (methionine, lysine and tryptophan) and higher content of anti-nutrients (Jannathulla et al., 2017a). In order to resolve these issues, researchers used a combination of plant protein sources with varying levels of success (Burr et al., 2012; Dayal et al., 2020). Fish are capable of modulating their digestive enzyme pattern in response to the quality and concentration of dietary nutrients and their sources (Gonzalez-Felix et al., 2010). These responses are the basis of the adaptation of fish to dietary changes, and knowing the mechanisms involved in this process can provide useful information to improve fish growth performance and health status (Eusebio and Coloso, 2002). However, the effect of utilisation of various plant protein sources together as a fishmeal substitute in L. calcarifer is scarce in the literature. Hence, present investigation is aimed to study the effect of inclusion of graded levels of various plant proteins on growth, digestive enzyme and fatty acid composition in L. calcarifer in relation to fishmeal substitution.

\section{Materials and methods}

\section{Experimental diets}

Five different plant protein sources such as soybean meal, groundnut oil cake, sunflower oil cake, wheat gluten meal and corn gluten meal, were purchased from the local markets in Chennai, India and were mixed in the ratio of 4:2:1:6.5:6.5 based on our earlier results (Madhubabu, 2019) to substitute fishmeal in the diet of Asian seabass.
Five iso-nitrogenous (401.13-407.33 $\mathrm{g} \mathrm{kg}^{-1}$ ) and iso-lipidic (150.30-155.15 $\mathrm{g} \mathrm{kg}^{-1}$ ) diets were formulated using locally available ingredients listed in Table 1 . The experimental diets were prepared by replacing fishmeal $(\mathrm{w} / \mathrm{w})$ at the rate 0 (control), 25, 50, 75 and 100\% (FM-R0, FM-R25, FM-R50, FM-R75 and FM-R100, respectively). In preparing experimental diets, the coarse ingredients were powdered in a micro pulveriser and passed through a $0.5 \mathrm{~mm}$ sieve. The ground materials were thoroughly mixed by hand and to which, additives (vitamin, mineral mix and binder) followed by oil sources (fish oil and soy lecithin) were subsequently added. They were homogenised in an electric blender for $20 \mathrm{~min}$. The homogenised mash was hydrated with deionised water (500 ml kg-1 of mash) and kneaded into a dough. It was steamed for $5 \mathrm{~min}$ at atmospheric pressure and pelleted in a table top pelletiser with a $2 \mathrm{~mm}$ diameter die. The pellets were dried in a forced-air oven at $60^{\circ} \mathrm{C}$ to bring down the moisture content to $<10 \%$ and stored in a refrigerator until use. Proximate, essential amino acids and fatty acid composition of experimental diets are presented in Table 2.

\section{Experimental feeding}

Juveniles of Asian seabass procured from the hatchery of ICAR-Central Institute of Brackishwater Aquaculture (ICAR-CIBA), Chennai, India were used in the present study. They were acclimatised to the experimental conditions for two weeks by feeding a formulated feed

Table 1. Ingredient and proximate composition of experimental diets containing graded levels of plant protein sources by replacing fishmeal $\left(\mathrm{g} \mathrm{kg}^{-1}\right.$ as fed basis $)$

\begin{tabular}{|c|c|c|c|c|c|}
\hline \multirow{2}{*}{ Particulars } & \multicolumn{5}{|c|}{ Experimental diets } \\
\hline & FM-R0 & FM-R25 & FM-R50 & FM-R75 & FM-R100 \\
\hline \multicolumn{6}{|c|}{ Ingredient composition } \\
\hline Fishmeal $^{1}$ & 350.0 & 262.5 & 175.0 & 87.5 & - \\
\hline Plant protein mix $^{2}$ & - & 100.0 & 200.0 & 300.0 & 400.0 \\
\hline Mantis shrimp meal ${ }^{3}$ & 100.0 & 100.0 & 100.0 & 100.0 & 100.0 \\
\hline Soybean meal & 200.0 & 200.0 & 200.0 & 200.0 & 200.0 \\
\hline Groundnut oil cake & 40.0 & 40.0 & 40.0 & 40.0 & 40.0 \\
\hline Sunflower oil cake & 15.0 & 15.0 & 15.0 & 15.0 & 15.0 \\
\hline Whole wheat & 121.0 & 102.5 & 82.0 & 63.5 & 45.0 \\
\hline Broken rice & 30.0 & 30.0 & 30.0 & 30.0 & 30.0 \\
\hline Fish oil $^{1}$ & 74.0 & 78.0 & 82.0 & 86.0 & 90.0 \\
\hline Soy-lecithin ${ }^{4}$ & 40.0 & 42.0 & 46.0 & 48.0 & 50.0 \\
\hline Pre-mix ${ }^{5}$ & 20.0 & 20.0 & 20.0 & 20.0 & 20.0 \\
\hline Binder $^{6}$ & 10.0 & 10.0 & 10.0 & 10.0 & 10.0 \\
\hline
\end{tabular}

${ }^{1}$ Bismi Fisheries, Mayiladuthurai, Tamil Nadu, India

${ }^{2}$ Plant protein mix contains soybean meal, groundnut oil cake, sunflower oil cake, wheat gluten meal and corn gluten meal at the ratio of 4:2:1:6.5:6.5

${ }^{3}$ Ismail haji Abdullah and Co., Chennai, Tamil Nadu, India

${ }^{4}$ Real Soy Enterprises, Madhya Pradesh, India

${ }^{5}$ Pre-mix (per 100 g): Vitamin A-200,000 IU, Vitamin D-40,000 IU, Vitamin E-30 U, Vitamin K-40 mg, Riboflavin-80 mg, Capantothenate-100 mg,

Nicotinamide-400 mg, Vitamin B12-0.24 mg, Choline chloride-6 g, Ca-30 g, Mn-1.1 g, I-40 mg, Fe-300 mg, Zn-0.6 g, Cu-80 mg, Co-18 mg

(Sarabhai Zydus Animal Health Ltd., Vadodara, Gujarat, India)

${ }^{6}$ Pegabind, Bentoli Agri-Nutrition Asia Pvt. Ltd., Singapore

Other feed ingredients were purchased from local markets around Chennai, Tamil Nadu, India 
Table 2. Proximate, essential amino acid and fatty acid composition of experimental diets containing graded levels of plant protein sources by replacing fishmeal

\begin{tabular}{|c|c|c|c|c|c|}
\hline \multirow{2}{*}{ Particulars } & \multicolumn{5}{|c|}{ Experimental diets } \\
\hline & FM-R0 & FM-R25 & FM-R50 & FM-R75 & FM-R100 \\
\hline \multicolumn{6}{|c|}{ Proximate composition (\% as fed basis) } \\
\hline Moisture & 92.12 & 91.30 & 91.50 & 91.70 & 92.40 \\
\hline Crude protein & 401.13 & 407.33 & 405.20 & 402.68 & 406.31 \\
\hline Ether extract & 155.15 & 150.30 & 150.75 & 151.97 & 151.48 \\
\hline Crude fibre & 30.72 & 36.64 & 38.53 & 39.64 & 41.09 \\
\hline $\mathrm{NFE}^{1}$ & 185.79 & 197.90 & 207.50 & 218.80 & 224.54 \\
\hline Total ash & 135.09 & 116.53 & 106.52 & 95.21 & 84.18 \\
\hline \multicolumn{6}{|c|}{ Essential amino acids (g per $16 \mathrm{~g} \mathrm{~N}$ ) } \\
\hline$\overline{A r g}$ & 2.86 & 2.58 & 2.34 & 2.24 & 1.93 \\
\hline His & 1.31 & 1.10 & 1.10 & 1.06 & 1.07 \\
\hline Ile & 1.98 & 1.88 & 1.85 & 1.84 & 1.79 \\
\hline Leu & 2.89 & 3.30 & 3.73 & 4.01 & 4.28 \\
\hline Lys & 2.54 & 2.27 & 1.98 & 1.68 & 1.37 \\
\hline Met & 1.03 & 0.96 & 0.94 & 0.87 & 0.84 \\
\hline Phe & 1.81 & 1.81 & 1.86 & 1.96 & 2.23 \\
\hline Thr & 1.56 & 1.62 & 1.50 & 1.49 & 1.40 \\
\hline $\operatorname{Trp}$ & 0.51 & 0.45 & 0.42 & 0.40 & 0.38 \\
\hline Val & 1.94 & 1.87 & 1.76 & 1.74 & 1.68 \\
\hline \multicolumn{6}{|c|}{ Fatty acids (\% total fatty acids) } \\
\hline $\mathrm{C} 14: 0$ & 6.43 & 6.42 & 6.31 & 6.31 & 6.44 \\
\hline C15:0 & 0.73 & 0.70 & 0.66 & 0.62 & 0.59 \\
\hline C16:0 & 19.66 & 19.29 & 18.11 & 16.47 & 15.03 \\
\hline C17:0 & 0.87 & 0.71 & 0.69 & 0.71 & 0.67 \\
\hline C18:0 & 5.69 & 5.53 & 5.30 & 5.22 & 5.09 \\
\hline $\mathrm{C} 20: 0$ & 0.48 & 0.52 & 0.49 & 0.53 & 0.50 \\
\hline $\mathrm{C} 24: 0$ & 0.23 & 0.20 & 0.23 & 0.22 & 0.19 \\
\hline C16:1 & 4.78 & 4.63 & 4.57 & 4.44 & 4.35 \\
\hline C18:1n9 & 14.59 & 14.63 & 14.86 & 15.85 & 16.63 \\
\hline $\mathrm{C} 18: \ln 7$ & 3.38 & 3.07 & 2.95 & 2.82 & 2.55 \\
\hline C20:1 & 0.65 & 0.58 & 0.49 & 0.52 & 0.59 \\
\hline C18:2n6 & 16.47 & 15.42 & 15.61 & 16.07 & 16.55 \\
\hline$\gamma \mathrm{C} 18: 3 \mathrm{n} 6$ & 0.69 & 0.71 & 0.72 & 0.69 & 0.63 \\
\hline$\alpha \mathrm{C} 18: 3 \mathrm{n} 3$ & 2.11 & 2.16 & 2.24 & 2.29 & 2.36 \\
\hline $\mathrm{C} 20: 2 \mathrm{n} 6$ & 0.21 & 0.20 & 0.20 & 0.21 & 0.22 \\
\hline C20:3n6 & 0.32 & 0.38 & 0.43 & 0.46 & 0.53 \\
\hline $\mathrm{C} 20: 4 \mathrm{n} 6$ & 1.76 & 1.82 & 1.84 & 1.85 & 1.88 \\
\hline $\mathrm{C} 20: 5 \mathrm{n} 3$ & 9.42 & 9.04 & 8.61 & 8.37 & 8.03 \\
\hline $\mathrm{C} 22: 6 \mathrm{n} 3$ & 6.48 & 6.36 & 6.25 & 6.13 & 6.05 \\
\hline
\end{tabular}

All the values are the mean of three replicates.

${ }^{1}$ Nitrogen free extract (Calculated by difference)

(400 $\mathrm{g} \mathrm{kg}^{-1}$ crude protein and $150 \mathrm{~g} \mathrm{~kg}^{-1}$ ether extract) developed at ICAR-CIBA, Chennai, India. Postacclimatisation, a total of 300 healthy and uniform sized fish $(6.09 \pm 0.25 \mathrm{~g})$ were randomly stocked in fifteen $500 \mathrm{l}$ $(1.31 \times 0.64 \times 0.73 \mathrm{~m})$ oval-shaped fiberglass reinforced plastic (FRP) tanks. All the experimental tanks were provided with sand-filtered seawater and continuous aeration by air diffuser stones, were closed with fibremat to prevent escape of animals and to avoid external disturbances. Each treatment had three replicates and each replicate contained twenty fish. Individual fish length and weight were recorded at the beginning of the experiment and feeding trial was conducted for 45 days. Fish were hand fed to satiation for an hour, twice daily (09:30 and 16:00 hrs). After feeding, uneaten feed pellets (if any) were siphoned out from the tanks daily, using a clean Falcon tube and dried at $60^{\circ} \mathrm{C}$ in a hot air oven to assess the feed intake. Animals were group weighed at fortnightly intervals for adjusting the feed ration. During the experimental period, about $80 \%$ 
of water was exchanged before the first feeding, every day and water quality parameters such as temperature $\left(28.47 \pm 1.58^{\circ} \mathrm{C}\right)$, salinity $(26.14 \pm 1.57 \%), \mathrm{pH}(8.24 \pm 0.63)$, dissolved oxygen $\left(8.01 \pm 0.71 \mathrm{mg} \mathrm{l}^{-1}\right)$ and ammonia-N $\left(0.08 \pm 0.01 \mathrm{mg} \mathrm{l}^{-1}\right)$ were maintained at optimal levels. At the end of the experiment, the fish were anesthetised using 2-phenoxyethanol at a dose of $0.3 \mathrm{ml} \mathrm{l}^{-1}$ (Nandakumar et al., 2017) and weight was measured individually to determine the growth parameters viz, weight gain (WG), average daily growth (ADG), specific growth rate (SGR), daily growth coefficient (DGC), feed conversion ratio (FCR), protein efficiency ratio (PER), apparent protein utilisation (APU) and survival as follows:

WG $(\%)=$ Final body weight $(\mathrm{g})$ - Initial body weight $(\mathrm{g})$ / Initial body weight $(\mathrm{g}) \times 100$

ADG $\left(\mathrm{mg} \mathrm{day}^{-1}\right)=($ Final body weight $(\mathrm{g})$ - Initial body weight (g) / Days of experiment

SGR $=[\ln$ Final body weight) $-\ln$ Initial body weight) $]$ / Days of experiment $\mathrm{x} 100$

DGC $=\left[\right.$ Final body weight ${ }^{1 / 3}-$ Initial body weight $\left.{ }^{1 / 3}\right] /$ Days of experiment $\mathrm{x} 100$

$\mathrm{FCR}=$ Feed intake $(\mathrm{g}) /$ Weight gain $(\mathrm{g})$

PER $=$ Weight gain $(\mathrm{g}) /$ Protein intake $(\mathrm{g})$

APU $=$ Protein gain $(\mathrm{g}) /$ Protein intake $(\mathrm{g})$

Survival $(\%)=$ Final number of animals $/$ Initial number of animals x 100

Fish from each replicate treatment (total 15 fish per treatment) were dissected to separate the digestive tract such as stomach, pyloric caeca, liver, anterior and posterior intestine to assess the activity of digestive enzymes. In addition, another fifteen fish from each treatment (five fish per replicate) that were not used for the measurement of digestive enzyme activity, were analysed for carcass proximate and fatty acid composition.

\section{Biochemical analysis}

Proximate composition was determined by AOAC (1997) method. Amino acid profiles were analysed using a pre-column derivatisation HPLC gradient system (Shimadzu Corp, LC-30AD) after hydrolysing the samples with $6 \mathrm{~N}$ hydrochloric acid in a sealed tube filled with nitrogen for $22 \mathrm{~h}$ at $110^{\circ} \mathrm{C}$ in an oven (Finlayson, 1964; Jannathulla et al., 2017b). Tryptophan, being liable to acid hydrolysis, was measured after alkali hydrolysis by spectrophotometric method at $500 \mathrm{~nm}$ (Sastry and Tammuru, 1985). Fatty acid methyl esters (FAMEs) were prepared according to Metcalfe et al. (1966) and was quantified by a gas chromatograph (GC-2014 Shimadzu) (Khan etal., 2018). The total soluble protein was determined as per Lowry et al. (1951) in a UV-VIS spectrophotometer (UV-1800, Shimadzu, Japan). All the digestive enzymes, including pepsin, trypsin, chymotrypsin, amylase, carboxypeptidase-A, carboxypeptidase-B, acid phosphatase, alkaline phosphatase and lipase were measured as per the methods described by Anson (1938), Erlanger et al. (1961), Hummel (1959), Bernfeld (1955), Folk and Schirmer (1963), Folk et al. (1960), Walter and Schutt (1974) and Winkler and Stuckmann (1979) respectively and their activity was expressed as $\mathrm{U} \mathrm{mg}$ protein ${ }^{-1}$.

\section{Statistical analysis}

Experimental data on growth and body composition were statistically analysed by one-way analysis of variance (ANOVA). Two-way ANOVA was performed using two different factors viz, level of fishmeal substitution $(0,25,50,75$ and $100 \%)$ and different parts of the digestive tract (stomach, pyloric caeca, liver, anterior and posterior intestine) to find difference in digestive enzyme activity. The statistical package for social science (SPSS 17.0) was used to analyse data obtained in the present investigation and means were compared using the Tukey's test at significance level of $p<0.05$. Prior to statistical evaluation, data were checked for determining the homogeneity of variance after ascertaining the normal distribution. Broken-line regression was carried out to find an optimal substitution level of fishmeal using a combination of plant proteins in the diet of Asian seabass.

\section{Results and discussion}

Several studies conducted earlier to explore the utilisation of various plant proteins such as soybean meal (Tantikitti et al., 2005), lupin concentrate, wheat gluten meal (Glencross et al., 2011), canola meal (Plaipetch and Yakupitiyage, 2012) and corn gluten meal (Nandakumar et al., 2017) in Asian seabass showed $<50 \%$ fishmeal substitution. Jannathulla et al. (2018b) suggested that this could partly be attributed to the deficiency of limiting amino acids, in particular methionine and lysine.

Boonyaratpalin et al. (1998) reported that the solvent extracted soybean meal could replace 10 to $15 \%$ dietary fishmeal without having any deleterious effect in Asian seabass and also suggested that the limitation in soybean meal usage is mainly attributed to the presence of anti-nutritional factors, especially trypsin inhibitor. Though the meals of gluten from wheat and corn were identified as a potential protein source (60 to $80 \%$ protein), beyond the inclusion of $10 \%$ by replacing an equal quantity of fishmeal, significantly $(p<0.05)$ affected digestibility and growth of Asian seabass (Nandakumar et al., 2017). Hence, a combination of plant protein sources with soybean meal, wheat gluten meal, corn gluten meal, groundnut oil cake and sunflower oil cake was used to substitute fishmeal in our study. The results showed that 
fish fed with diet containing up to $50 \%$ plant proteins by substituting fishmeal $(\mathrm{w} / \mathrm{w})$ had no negative effect on growth rate in terms of $\mathrm{WG}, \mathrm{ADG}, \mathrm{SGR}$ and DGC (Table 3). Our results corroborated the findings of De Francesco et al. (2007), who reported that plant proteins could replace $>50 \%$ of fishmeal in the diet of gilthead seabream. This improved performance with a combination of plant proteins were mainly attributed to the compensation of deficient amino acids. It is noteworthy that methionine and lysine are the most limiting amino acids in the selected plant protein sources and the same was also available in fishmeal. Though level of methionine and lysine were reduced from 1.18 to $0.91 \mathrm{~g}$ per $16 \mathrm{~g} \mathrm{~N}$ and 2.75 to $1.47 \mathrm{~g}$ per $16 \mathrm{~g} \mathrm{~N}$, respectively in the experimental diets with increasing the inclusion of plant proteins, the growth performance of fish fed diet with plant protein sources up to $50 \%$ was on par with control group (FM-R0). This clearly indicates that a combination of plant proteins would be better in compensating deficient amino acids rather than individual source. However, broken-line analysis (Fig. 1) indicated that optimal fishmeal substitution using a combination of plant protein was $46.7 \%$ in the diet of Asian seabass.

On the other hand, when the replacement of fishmeal was further increased ( 75 to $100 \%$ ), growth indices of experimental fish exhibited significant $(\mathrm{p}<0.05)$ decrease which could be attributed to the higher content of anti-nutritional factors (Jannathulla et al., 2017a). The SGR obtained in the present study was in the range of 2.74-3.48 whereas, comparatively lower SGR was reported by Kissil and Lupatsh (2004) in gilthead sea bream (1.28), by Tomas et al. (2011) in Dentex (0.69) and by Guroy et al. (2013) in catfish when fish fed a diet with 100\% plant proteins as fishmeal substitute. However, the results obtained in the present study are similar to the earlier reports in Asian seabass fed corn gluten meal as substitute

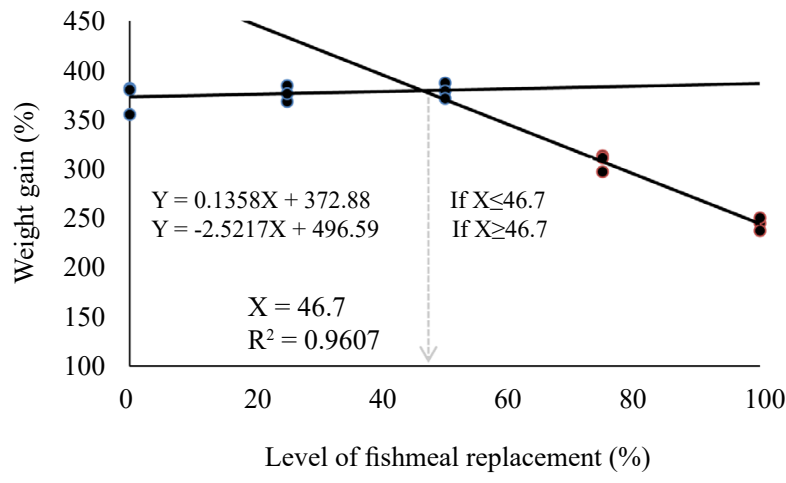

Fig. 1. Estimation of optimal replacement level of fishmeal with plant proteins in the diet of $L$. calcarifer using broken-line analysis

for fishmeal at moderate level (Nandakumar et al., 2017). The difference noticed between the studies could be due to the variation in species, age, size and culture conditions. But in contrast, Kissil and Lupatsh (2004) and Tomas et al. (2011) reported a higher SGR in fish fed $100 \%$ fishmeal substituted diet using plant proteins than those fed control diet (no replacement). However, the present findings are in concurrence with rainbow trout (Gomes et al., 1995), European seabass (Kaushik et al., 2004), Turbot (Fournier et al., 2004) and Atlantic salmon (Espe et al., 2006) fed plant ingredients as a major protein source in their diets. The FCR gradually increased $(p<0.05)$ from 1.82 to 2.26 with increasing fishmeal substitution. The result is in agreement with the finding of Nandakumar et al. (2017). On the contrary, the FCR was not significantly $(\mathrm{p}<0.05)$ affected due to the inclusion of plant proteins in a previous study with European seabass (Kaushich et al., 2004). Survival of the fish fed with diets having 50\% plant proteins did not differ significantly (88.33 to $96.66 \%$ ) whereas, it was reduced $(\mathrm{p}<0.05)$ to $70 \%$ with FM-R75

Table 3. Growth performances of $L$. calcarifer fed with experimental diets having graded levels of plant protein sources by replacing fishmeal $(n=3)$

\begin{tabular}{|c|c|c|c|c|c|c|c|c|}
\hline \multirow{2}{*}{ Particulars } & \multicolumn{5}{|c|}{ Experimental diets } & \multirow{2}{*}{$\operatorname{SEM}( \pm)$} & \multirow{2}{*}{$\mathrm{CV}(\%)$} & \multirow{2}{*}{$\mathrm{p}$ value } \\
\hline & FM-R0 & FM-R25 & FM-R50 & FM-R75 & FM-R100 & & & \\
\hline Initial weight (g) & $6.35^{\mathrm{a}}$ & $6.01^{\mathrm{a}}$ & $5.95^{\mathrm{a}}$ & $6.11^{\mathrm{a}}$ & $6.04^{\mathrm{a}}$ & 0.150 & 8.357 & 0.887 \\
\hline Final weight (g) & $29.99^{a}$ & $28.62^{\mathrm{a}}$ & $28.52^{\mathrm{a}}$ & $24.88^{b}$ & $20.77^{\mathrm{c}}$ & 1.989 & 6.988 & 0.002 \\
\hline Weight gain $(\%)$ & $372.65^{\mathrm{a}}$ & $376.72^{\mathrm{a}}$ & $379.44^{\mathrm{a}}$ & $307.46^{\mathrm{b}}$ & $244.42^{\mathrm{c}}$ & 62.172 & 3.087 & $<0.001$ \\
\hline $\mathrm{ADG}^{1}\left(\mathrm{mg}\right.$ day $\left.^{-1}\right)$ & $525.40^{\mathrm{a}}$ & $502.59^{a}$ & $501.63^{\mathrm{a}}$ & $417.25^{\mathrm{b}}$ & $327.55^{\mathrm{c}}$ & 544.971 & 6.754 & $<0.001$ \\
\hline $\mathrm{SGR}^{2}$ & $3.45^{\mathrm{a}}$ & $3.47^{\mathrm{a}}$ & $3.48^{\mathrm{a}}$ & $3.12^{\mathrm{b}}$ & $2.74^{\mathrm{c}}$ & 0.002 & 1.595 & $<0.001$ \\
\hline $\mathrm{DGC}^{3}$ & $2.78^{\mathrm{a}}$ & $2.75^{\mathrm{a}}$ & $2.75^{\mathrm{a}}$ & $2.42^{\mathrm{b}}$ & $2.06^{\mathrm{c}}$ & 0.002 & 2.540 & $<0.001$ \\
\hline $\mathrm{FCR}^{4}$ & $1.82^{\mathrm{c}}$ & $1.86^{\mathrm{c}}$ & $1.84^{\mathrm{c}}$ & $2.07^{\mathrm{b}}$ & $2.26^{\mathrm{a}}$ & 0.002 & 2.596 & $<0.001$ \\
\hline $\mathrm{PER}^{5}$ & $1.37^{\mathrm{a}}$ & $1.34^{\mathrm{a}}$ & $1.35^{\mathrm{a}}$ & $1.20^{\mathrm{b}}$ & $1.10^{\mathrm{c}}$ & 0.001 & 2.064 & $<0.001$ \\
\hline $\mathrm{APU}^{6}$ & $26.40^{\mathrm{ab}}$ & $25.42^{b}$ & $26.44^{\mathrm{a}}$ & $23.49^{c}$ & $21.59^{d}$ & 0.164 & 2.158 & $<0.001$ \\
\hline Survival (\%) & $96.66^{\mathrm{a}}$ & $91.66^{\mathrm{a}}$ & $88.33^{\mathrm{a}}$ & $70.00^{\mathrm{b}}$ & $53.33^{\mathrm{c}}$ & 32.957 & 9.444 & 0.001 \\
\hline
\end{tabular}

Means bearing different superscript letters within in the row significantly $(\mathrm{p}<0.05)$ differ each other

${ }^{1}$ Average daily growth; ${ }^{2}$ Specific growth rate; ${ }^{3}$ Daily growth coefficient; ${ }^{4}$ Feed conversion ratio; ${ }^{5}$ Protein efficiency ratio; ${ }^{6}$ Apparent protein utilisation 
and to $53.33 \%$ with FM-R100. This is attributed to the poor palatability and intake due to higher inclusion level of plant proteins.

Utilisation of feed by the fish mainly depends on nutrient levels, ingredients in the feed, feeding time, amount of feed and activity of the digestive enzymes in the fish. Of all the dietary treatments, fish fed with diets FMR0, FM-R-25 and FM-R50 showed significantly $(\mathrm{p}<0.05)$ higher pepsin activity (14.76-14.99 U mg protein ${ }^{-1}$ ) compared to other groups. Trypsin, amylase and chymotrypsin were found in all the analysed digestive parts except stomach and was higher in the anterior intestine (6.62 $\mathrm{U} \mathrm{mg}$ protein $\left.{ }^{-1}\right)$, posterior intestine (4.33 $\mathrm{U} \mathrm{mg}$ protein $\left.{ }^{-1}\right)$ and pyloric caeca (2.36 $\mathrm{U} \mathrm{mg}$ protein $\left.^{-1}\right)$, respectively. The activity of trypsin and chymotrypsin decreased with increasing fishmeal substitution and the reverse was true for amylase (Table 4). Krogdahl et al. (2003) studied the effects on digestive enzymes with the incorporation of graded levels of soybean meal in Atlantic salmon and showed a lower digestive enzymatic activity with increase of dietary soybean level. Lin and Luo (2011) studied the replacement of fishmeal with soybean meal on growth, digestive enzymes and transaminase activities in juvenile tilapia. Significant decrease in protease activities were observed in both intestinel and hepatopancreas, but not in the amylase activity in hepatopancreas among the dietary treatments. All the digestive parts had an activity of carboxypeptidase-A, carboxypeptidase-B and acid phosphatase except liver. Posterior intestine had the highest activity of both carboxypeptidase-A and B (5.43 and 8.51 U mg protein ${ }^{-1}$ ), while acid phosphatase was high in pyloric caeca $\left(0.87 \mathrm{U} \mathrm{mg}\right.$ protein $\left.^{-1}\right)$. There was no significant difference in carboxypeptidase-A up to $75 \%$ fishmeal substitution and was limited to $50 \%$ for carboxypeptidase- $\mathrm{B}$ and acid phosphatase. The highest activity of alkaline phosphatase was found in the anterior intestine (5.16 $\mathrm{U} \mathrm{mg}$ protein $^{-1}$ ) followed by pyloric caeca and posterior intestine, while it was not detected in both stomach and liver. However, the dietary change had no influence $(\mathrm{p}=0.046)$ on alkaline phosphatase activity irrespective of the digestive tract (4.48-4.75 $\mathrm{U} \mathrm{mg}$ protein $\left.^{-1}\right)$. Activity of lipase was detected in all the digestive parts and was high in the pyloric caeca (1.32 $\mathrm{U} \mathrm{mg} \mathrm{protein}^{-1}$ ). Fish fed with FM-R25 diet had the highest activity of lipase compared to other dietary groups (0.97-1.09 $\mathrm{U} \mathrm{mg}$ protein $^{-1}$ ). Jalili et al. (2012) studied the effects of replacement of fishmeal with graded levels of plant protein sources on feed utilisation and digestive enzyme activities in carnivorous feeding habit of rainbow trout. Complete replacement of fishmeal resulted in significant reduction of alkaline protease and lipase activities, but not amylase activity in rainbow trout. $\mathrm{Yu}$ et al. (2013) studied the effects of replacement of fishmeal with soybean meal on growth, body composition and digestive enzyme activities in the intestine and hepatopancreas of Chinese sucker. Digestive enzyme activities showed decreasing trend with increasing dietary

Table 4. Digestive enzymes activities ( $\mathrm{U}$ mg protein $\left.{ }^{-1}\right)$ in various disgestive tissues of $L$. calcarifer fed with experimental diets having graded levels of plant protein sources by replacing fishmeal $(n=3)$

\begin{tabular}{|c|c|c|c|c|c|c|c|c|c|}
\hline \multirow[b]{2}{*}{ Particulars } & \multicolumn{9}{|c|}{ Digestive enzymes } \\
\hline & Pepsin & Trypsin & Chymotrypsin & Amylase & $\begin{array}{l}\text { Carboxy- } \\
\text { peptidase A }\end{array}$ & $\begin{array}{l}\text { Carboxy- } \\
\text { peptidase B }\end{array}$ & $\begin{array}{l}\text { Acid } \\
\text { phosphatase }\end{array}$ & $\begin{array}{l}\text { Alkaline } \\
\text { phosphatase }\end{array}$ & Lipase \\
\hline \multicolumn{10}{|c|}{ Experimental diets (A) } \\
\hline FM-R0 & $14.99^{\mathrm{a}}$ & $4.34^{\mathrm{a}}$ & $2.12^{\mathrm{a}}$ & $3.47^{\mathrm{b}}$ & $3.32^{\mathrm{a}}$ & $5.56^{\mathrm{a}}$ & $0.62^{\mathrm{a}}$ & $4.63^{\mathrm{a}}$ & $1.08^{\mathrm{ab}}$ \\
\hline FM-R25 & $14.81^{\mathrm{a}}$ & $4.41^{\mathrm{a}}$ & $2.16^{\mathrm{a}}$ & $3.86^{\mathrm{a}}$ & $3.35^{\mathrm{a}}$ & $5.60^{\mathrm{a}}$ & $0.59^{\mathrm{abc}}$ & $4.66^{\mathrm{a}}$ & $1.12^{\mathrm{a}}$ \\
\hline FM-R50 & $14.76^{\mathrm{a}}$ & $4.55^{\mathrm{a}}$ & $2.08^{\mathrm{a}}$ & $4.01^{\mathrm{a}}$ & $3.32^{\mathrm{a}}$ & $5.55^{\mathrm{a}}$ & $0.60^{\mathrm{ab}}$ & $4.75^{\mathrm{a}}$ & $1.09^{\mathrm{ab}}$ \\
\hline FM-R75 & $9.75^{\mathrm{b}}$ & $3.55^{\mathrm{b}}$ & $2.01^{\mathrm{a}}$ & $3.94^{\mathrm{a}}$ & $3.29^{\mathrm{a}}$ & $5.17^{\mathrm{b}}$ & $0.55^{\mathrm{bc}}$ & $4.63^{\mathrm{a}}$ & $1.00^{\mathrm{bc}}$ \\
\hline FM-R100 & $8.20^{\mathrm{c}}$ & $2.97^{\mathrm{c}}$ & $1.50^{\mathrm{b}}$ & $3.70^{\mathrm{ab}}$ & $2.93^{\mathrm{b}}$ & $4.65^{\mathrm{c}}$ & $0.52^{\mathrm{c}}$ & $4.48^{\mathrm{a}}$ & $0.97^{\mathrm{c}}$ \\
\hline \multicolumn{10}{|l|}{ Digestive parts (B) } \\
\hline Stomach & $20.55^{\mathrm{a}}$ & - & - & - & $1.27^{\mathrm{d}}$ & $1.69^{\mathrm{d}}$ & $0.40^{\mathrm{d}}$ & - & $0.59^{\mathrm{c}}$ \\
\hline Pyloric caeca & $4.45^{\mathrm{b}}$ & $2.53^{\mathrm{c}}$ & $2.36^{\mathrm{a}}$ & $3.89^{\mathrm{b}}$ & $2.58^{\mathrm{c}}$ & $3.96^{\mathrm{c}}$ & $0.87^{\mathrm{a}}$ & $4.87^{\mathrm{b}}$ & $1.32^{\mathrm{a}}$ \\
\hline Liver & - & $2.19^{\mathrm{d}}$ & $1.98^{\mathrm{b}}$ & $2.65^{\mathrm{c}}$ & - & - & - & - & $1.03^{\mathrm{b}}$ \\
\hline Anterior intestine & - & $6.65^{\mathrm{a}}$ & $1.94^{\mathrm{b}}$ & $4.32^{\mathrm{a}}$ & $3.70^{\mathrm{b}}$ & $7.06^{\mathrm{b}}$ & $0.55^{\mathrm{b}}$ & $5.16^{\mathrm{a}}$ & $1.06^{\mathrm{b}}$ \\
\hline Posterior intestine & - & $4.48^{\mathrm{b}}$ & $1.61^{\mathrm{c}}$ & $4.33^{\mathrm{a}}$ & $5.43^{\mathrm{a}}$ & $8.51^{\mathrm{a}}$ & $0.47^{\mathrm{c}}$ & $3.87^{\mathrm{c}}$ & $1.25^{\mathrm{a}}$ \\
\hline \multicolumn{10}{|l|}{ p value } \\
\hline $\mathrm{A}$ & $<0.001$ & $<0.001$ & $<0.001$ & 0.022 & $<0.001$ & $<0.001$ & 0.046 & 0.051 & 0.022 \\
\hline $\mathrm{B}$ & $<0.001$ & $<0.001$ & $<0.001$ & $<0.001$ & $<0.001$ & $<0.001$ & $<0.001$ & $<0.001$ & $<0.001$ \\
\hline$A \times B$ & $<0.001$ & 0.113 & $<0.001$ & 0.006 & 0.487 & $<0.001$ & 0.077 & 0.024 & 0.075 \\
\hline $\operatorname{SEM}( \pm)$ & 0.586 & 0.108 & 0.024 & 0.097 & 0.017 & 0.056 & 0.004 & 0.018 & 0.011 \\
\hline CV $(\%)$ & 8.059 & 10.873 & 10.366 & 10.755 & 5.343 & 5.875 & 14.520 & 3.789 & 12.866 \\
\hline
\end{tabular}

Mean bearing different superscript letters in a column within the main effects between the categories significantly $(\mathrm{p}>0.05)$ differ 
soybean meal. When fishmeal was replaced beyond $60 \%$, the protease and lipase activities were reduced significantly in both intestine and hepatopancreas.

The carcass proximate composition of Asian seabass fed with experimental diets containing varying levels of plant proteins showed significant $(\mathrm{p}<0.05)$ difference in lipid and was high in FM-R100 fed group. This observation is similar to the result obtained in other fish species fed diets having plant protein blend (Cabral et al., 2011). However, other proximate principles were not affected due to the dietary change in our study (Table 5). A similar trend was observed by Kaushik et al. (2004) in European seabass fed diet with almost complete replacement of fishmeal. In the present study, the dietary change has a remarkable impact on carcass fatty acids and among them, C16:0, C18:0, C16:1, C18:1n-9, C18:2n-6 and C22:6 were particularly abundant and contributes more than $50 \%$ of the total fatty acids. This agrees with the observation on other fish like Atlantic salmon (Pratoomyot et al., 2010), Senegalese sole (Cabral et al., 2011) and European seabass (Messina et al., 2013). Fatty acids like C16:1, C20:4, C20:5 and C22:6 were found significantly $(p<0.05)$ decreased with increasing fishmeal substitution, while the reverse trend was observed for C18:1n-9, C18:2n-6. In most cases, fatty acid composition of experimental diets was reflected in the body composition. Similar findings were observed in the present study, however, certain fatty acids appeared to be retained or actively synthesised, though their levels were lower in the diet. Gonzalez-Felix et al. (2002) suggested that this could be due to the sparing and retention phenomena of the cultured species. On the other hand, the level of certain

Table 5. Carcass proximate and fatty acid composition of $L$. calcarifer fed with experimental diets having graded levels of plant protein sources by replacing fishmeal $(\mathrm{n}=3)$

\begin{tabular}{|c|c|c|c|c|c|c|c|c|}
\hline \multirow{2}{*}{ Particulars } & \multicolumn{5}{|c|}{ Experimental diets } & \multirow{2}{*}{$\operatorname{SEM}( \pm)$} & \multirow{2}{*}{$\mathrm{CV}(\%)$} & \multirow{2}{*}{$\mathrm{p}$ value } \\
\hline & FM-R0 & FM-R25 & FM-R50 & FM-R75 & FM-R100 & & & \\
\hline \multicolumn{9}{|c|}{ Proximate composition ( $\mathrm{g} \mathrm{kg}^{-1}$ wet weight basis) } \\
\hline Moisture & $695.07^{\mathrm{a}}$ & $698.60^{\mathrm{a}}$ & $697.03^{\mathrm{a}}$ & $692.27^{\mathrm{a}}$ & $692.27^{\mathrm{a}}$ & 10.330 & 0.607 & 0.339 \\
\hline Crude protein & $167.90^{\mathrm{a}}$ & $166.03^{\mathrm{a}}$ & $168.17^{\mathrm{a}}$ & $168.07^{\mathrm{a}}$ & $168.63^{\mathrm{a}}$ & 6.737 & 2.032 & 0.893 \\
\hline Crude lipid & $76.37^{c}$ & $77.03^{\mathrm{c}}$ & $77.13^{c}$ & $85.10^{\mathrm{b}}$ & $87.00^{\mathrm{a}}$ & 0.518 & 1.172 & $<0.001$ \\
\hline Crude fibre & $9.53^{\mathrm{a}}$ & $9.37^{\mathrm{a}}$ & $8.47^{\mathrm{a}}$ & $9.27^{\mathrm{a}}$ & $9.50^{\mathrm{a}}$ & 0.578 & 10.844 & 0.714 \\
\hline $\mathrm{NFE}^{1}$ & $6.37^{\mathrm{a}}$ & $3.47^{\mathrm{a}}$ & $2.87^{\mathrm{a}}$ & $1.73^{\mathrm{a}}$ & $0.73^{\mathrm{a}}$ & 3.484 & 80.763 & 0.152 \\
\hline Total ash & $44.80^{\mathrm{a}}$ & $45.57^{\mathrm{a}}$ & $46.33^{\mathrm{a}}$ & $43.50^{\mathrm{a}}$ & $41.83^{\mathrm{a}}$ & 3.733 & 5.723 & 0.301 \\
\hline \multicolumn{9}{|c|}{ Fatty acid composition (\% total fatty acids) } \\
\hline C14:0 & $3.23^{\mathrm{ab}}$ & $3.27^{\mathrm{a}}$ & $3.19^{\mathrm{bc}}$ & $3.15^{\mathrm{c}}$ & $3.23^{\mathrm{ab}}$ & 0.001 & 1.199 & 0.038 \\
\hline $\mathrm{C} 15: 0$ & $0.60^{\mathrm{bc}}$ & $0.58^{\mathrm{c}}$ & $0.61^{\mathrm{b}}$ & $0.63^{\mathrm{ab}}$ & $0.66^{\mathrm{a}}$ & $<0.001$ & 2.834 & 0.005 \\
\hline C16:0 & $16.74^{\mathrm{a}}$ & $17.00^{\mathrm{a}}$ & $16.98^{\mathrm{a}}$ & $17.11^{\mathrm{a}}$ & $17.10^{\mathrm{a}}$ & 0.025 & 1.233 & 0.214 \\
\hline $\mathrm{C} 17: 0$ & $0.59^{\mathrm{a}}$ & $0.58^{\mathrm{a}}$ & $0.61^{\mathrm{a}}$ & $0.57^{\mathrm{a}}$ & $0.65^{\mathrm{a}}$ & 0.001 & 5.894 & 0.129 \\
\hline C18:0 & $6.07^{c}$ & $6.10^{\mathrm{bc}}$ & $6.17^{b}$ & $6.25^{\mathrm{a}}$ & $6.30^{\mathrm{a}}$ & 0.001 & 0.688 & 0.001 \\
\hline C20:0 & $0.79^{a}$ & $0.71^{\mathrm{c}}$ & $0.78^{\mathrm{a}}$ & $0.74^{\mathrm{bc}}$ & $0.75^{b}$ & $<0.001$ & 2.083 & 0.002 \\
\hline $\mathrm{C} 22: 0$ & $0.70^{\mathrm{ab}}$ & $0.64^{\mathrm{bc}}$ & $0.71^{\mathrm{ab}}$ & $0.60^{\mathrm{c}}$ & $0.77^{\mathrm{a}}$ & 0.001 & 6.388 & 0.011 \\
\hline $\mathrm{C} 24: 0$ & $0.16^{\mathrm{ab}}$ & $0.19^{\mathrm{a}}$ & $0.17^{\mathrm{ab}}$ & $0.14^{\mathrm{b}}$ & $0.15^{b}$ & $<0.001$ & 9.776 & 0.043 \\
\hline C16:1 & $6.57^{\mathrm{a}}$ & $6.58^{\mathrm{a}}$ & $6.42^{\mathrm{b}}$ & $6.32^{\mathrm{c}}$ & $6.27^{\mathrm{c}}$ & 0.001 & 0.675 & 0.000 \\
\hline C17:1 & $0.30^{\mathrm{a}}$ & $0.30^{\mathrm{a}}$ & $0.28^{\mathrm{a}}$ & $0.29^{\mathrm{a}}$ & $0.30^{\mathrm{a}}$ & $<0.001$ & 5.603 & 0.585 \\
\hline $\mathrm{C} 18: \ln 9$ & $12.30^{\mathrm{d}}$ & $12.48^{\mathrm{c}}$ & $12.54^{\mathrm{c}}$ & $12.66^{b}$ & $12.80^{\mathrm{a}}$ & 0.001 & 0.278 & 0.000 \\
\hline C18:1n7 & $3.31^{\mathrm{a}}$ & $3.29^{\mathrm{a}}$ & $3.32^{\mathrm{a}}$ & $3.33^{\mathrm{a}}$ & $3.35^{\mathrm{a}}$ & 0.002 & 1.603 & 0.725 \\
\hline C20:1 & $0.65^{\mathrm{a}}$ & $0.53^{\mathrm{bc}}$ & $0.57^{b}$ & $0.50^{\mathrm{c}}$ & $0.55^{\mathrm{bc}}$ & $<0.001$ & 4.480 & 0.001 \\
\hline $\mathrm{C} 22: 1$ & $0.14^{\mathrm{a}}$ & $0.17^{\mathrm{a}}$ & $0.16^{\mathrm{a}}$ & $0.15^{\mathrm{a}}$ & $0.16^{\mathrm{a}}$ & $<0.001$ & 8.501 & 0.089 \\
\hline C24:1 & $0.21^{\mathrm{a}}$ & $0.19^{\mathrm{a}}$ & $0.22^{\mathrm{a}}$ & $0.19^{\mathrm{a}}$ & $0.19^{\mathrm{a}}$ & $<0.001$ & 11.803 & 0.457 \\
\hline C18:2n6 & $15.95^{\mathrm{c}}$ & $16.57^{b}$ & $16.84^{\mathrm{ab}}$ & $17.04^{\mathrm{ab}}$ & $17.26^{\mathrm{a}}$ & 0.048 & 1.721 & 0.004 \\
\hline $\mathrm{C} 20: 2 \mathrm{n} 6$ & $0.12^{\mathrm{a}}$ & $0.13^{\mathrm{a}}$ & $0.13^{\mathrm{a}}$ & $0.13^{\mathrm{a}}$ & $0.11^{\mathrm{a}}$ & $<0.001$ & 14.374 & 0.604 \\
\hline$\gamma \mathrm{C} 18: 3$ & $0.80^{\mathrm{b}}$ & $0.85^{\mathrm{a}}$ & $0.80^{\mathrm{b}}$ & $0.88^{\mathrm{a}}$ & $0.86^{\mathrm{a}}$ & $<0.001$ & 2.018 & 0.002 \\
\hline$\alpha \mathrm{C} 18: 3 \mathrm{n} 3$ & $1.18^{\mathrm{c}}$ & $1.22^{\mathrm{b}}$ & $1.19^{c}$ & $1.26^{\mathrm{a}}$ & $1.23^{\mathrm{b}}$ & $<0.001$ & 1.052 & 0.000 \\
\hline $\mathrm{C} 20: 3 \mathrm{n} 6$ & $0.44^{\mathrm{a}}$ & $0.42^{\mathrm{a}}$ & $0.44^{\mathrm{a}}$ & $0.45^{\mathrm{a}}$ & $0.44^{\mathrm{a}}$ & $<0.001$ & 2.935 & 0.181 \\
\hline $\mathrm{C} 20: 4 \mathrm{n} 6$ & $1.59^{\mathrm{b}}$ & $1.60^{\mathrm{b}}$ & $1.66^{\mathrm{a}}$ & $1.53^{\mathrm{c}}$ & $1.38^{\mathrm{d}}$ & $<0.001$ & 1.671 & 0.000 \\
\hline $\mathrm{C} 20: 5 \mathrm{n} 3$ & $2.91^{\mathrm{a}}$ & $2.82^{\mathrm{ab}}$ & $2.74^{\mathrm{bc}}$ & $2.67^{\mathrm{c}}$ & $2.39^{d}$ & $<0.001$ & 1.845 & 0.000 \\
\hline $\mathrm{C} 22: 6 \mathrm{n} 3$ & $7.05^{\mathrm{a}}$ & $6.87^{\mathrm{b}}$ & $6.92^{\mathrm{ab}}$ & $5.85^{\mathrm{c}}$ & $5.34^{\mathrm{d}}$ & 0.003 & 1.151 & 0.000 \\
\hline
\end{tabular}

Means bearing different superscript letters within in the row differ significantly $(\mathrm{p}<0.05)$.

${ }^{1}$ Nitrogen free extract (Calculated by difference) 
fatty acids was low in carcass than the experimental diet due to the selective utilisation of such fatty acids for energy production (Caballero et al., 2002). Fish fed diet with FM-R100 (complete replacement) showed $(p<0.05)$ a low level of eicosapentaenoic acid (EPA) and docosahexaenoic acid (DHA) compared to other treatments, however, the sum of polyunsaturated fatty acids (PUFAs) content was not affected due to the higher content of C18:2 n-6. The result is in agreement with the findings obtained with gilthead seabream (Izquierdo et al., 2003). Gonzalez-Felix et al. (2002) reported that a plant-based diet, in which $90 \%$ of fish oil was replaced by soy oil, had no adverse effects on growth performance, but dramatically reduced body PUFAs content. This result is in agreement with the findings of Montero et al. (2005) in D. labrax while replacing fish oil using various plant oils viz, rapeseed, linseed and palm oils. The authors suggested to switch from plant oil to fish oil containing diet (finisher diet) prior to harvesting for an appropriate time to restore both EPA and DHA as they are most important fatty acids in human nutrition. A study with juveniles of Penaeus monodon (Khan, 2013) showed that a period of 30-days was required to restore both EPA and DHA by using a finisher diet (control diet with no fishmeal replacement) in both field and laboratory conditions, whereas finishing diet phase was 16 to 20 weeks in salmon fed a blend of rapeseed, linseed and fish oil (Bell et al., 2004). The variation in time phase between the studies could be due to species difference, weight of species, rearing and environmental conditions. Our data demonstrated that fatty acids like C16:0, C18:1n-9 and C18:2n-6 were abundant in fish carcass and formed nearly $40 \%$ of the total fatty acids. Fish fed post-experimental diets had a higher content of PUFAs (30.48 to $32.55 \%$ ) and saturated fatty acids (SFAs) (29.62 to $31.70 \%$ ) compared to mono-unsaturated fatty acids (MUFAs) (23.48 to $23.65 \%$ ). This result is contrary to the findings in other species (Paleari et al., 1997). Chen et al. (1995) reported a higher content of MUFAs instead of SFAs. Among the n- 6 series of PUFAs, C18:2 was predominant and gradually increased $(p<0.05)$ with increasing inclusion level of plant protein sources. In n-3 series of PUFAs, C22:6 dominated and gradually decreased $(\mathrm{p}<0.05)$ due to the inclusion of plant proteins. The sum of n- 6 fatty acids increased in fish carcass with increasing inclusion level of plant proteins, while the reverse trend was noticed in $n-3$ series, hence, the ratio of n-3/n-6 reduced from 0.72 to 0.50 .

The present investigation demonstrated that a combination of plant protein sources could substitute $50 \%$ of fishmeal in the diet of Asian seabass without having any adverse effect on growth performance. The findings of digestive enzyme profiles have given an insight into how the fish is adapting to fishmeal substitution by modulating enzyme profiles. Feeding fish with finisher diet (no fishmeal replacement) is imperative to restore the reduced PUFAs, in particular EPA and DHA when fishmeal has been replaced beyond $50 \%$. From the present results, it can be concluded that a blend of plant protein sources could be a potential alternative to fishmeal. Further studies on supplementation of crystalline amino acids, phosphorus, phytase and customised digestive enzymes could help to maximise utilisation of these ingredients by reducing inclusion level of fishmeal in the diet of Asian seabass.

\section{Acknowledgements}

The authors thank Dr. K. K. Vijayan and Dr. A. G. Ponniah, Former Directors, ICAR-CIBA, Chennai, India for providing all the necessary facilities to carry out the present work. This work was financially supported by the Indian Council of Agricultural Research (ICAR), New Delhi, India through the project, Outreach activity on nutrient profiling and evaluation of fish as a dietary component.

\section{References}

Anson, M. L. 1938. The estimation of pepsin, trypsin, papain and cathepsin with hemoglobin. J. Gen. Physiol., 22: 79-89. doi: 10.1085/jgp.22.1.79.

AOAC 1997. Official methods of analysis, $18^{\text {th }}$ edn. Association of Official Analytical Chemists, Washington DC, USA.

Bell, J. G., Henderson, R. J., Tocher, D. R. and Sargent, J. R. 2004. Replacement of dietary fish oil with increasing levels of linseed oil: Modification of flesh fatty acid compositions in Atlantic salmon (Salmo salar) using a fish oil finishing diet. Lipids, 39: 223-232. https://doi.org/10.1007/s11745004-1223-5.

Bernfeld, P. 1955. Amylases, alpha and beta. Methods Enzymol., 1: 149-158. http://dx.doi.org/10.1016/0076-6879(55) 01021-5.

Boonyaratpalin, M., Suraneiranat, P. and Tunpibal, T. 1998. Replacement of fish meal with various types of soybean products in diets for the Asian seabass, Lates calcarifer. Aquaculture, 161: 67-78.

Burr, G. S., Wolters, W. R., Barrows, F. T. and Hardy, R. W. 2012. Replacing fishmeal with blends of alternative proteins on growth performance of rainbow trout (Oncorhynchus mykiss) and early or late stage juvenile Atlantic salmon (Salmo salar). Aquaculture, 334: 110-116.

Caballero, M. J., Obach, A., Rosenlund, G., Montero, D., Gisvold, M. and Izquierdo, M. S. 2002. Impact of different dietary lipid sources on growth, lipid digestibility, tissue fatty acid composition and histology of rainbow trout, Oncorhynchus mykiss. Aquaculture, 214: 253-271. https:// doi.org/10.1016/S0044-8486(01)00852-3.

Cabral, E. M., Bacelar, M., Batista, S., Castro-Cunha, M., Ozorio, R. O. and Valente, L. M. 2011. Replacement of fishmeal by increasing levels of plant protein blends in 
diets for Senegalese sole (Solea senegalensis) juveniles. Aquaculture, 322: 74-81.

Chen, I. C., Chapman, F. A., Wei, C. I., Porteir, K. M. and O"Keefe, S. F. 1995. Differentiation of cultured and wild sturgeon (Acipencer oxyrinchus desotoi) based on fatty acid composition. J. Food Sci., 60: 631-635.

Dayal, J. S., Jannathulla, R., Ambasankar, K. and Muralidhar, M. 2020. Aspergillus niger fermented plant protein mix as a potential substitute for fishmeal in the diet of Penaeus vannamei (Boone, 1931). Aquac. Nutr., 26: 853-865. https://doi.org/10.1111/anu.13044.

De Francesco, M., Parisi, G., Perez-Sanchez, J., GomezRequeni, P., Medale, F., Kaushik, S. J., Mecatti, M. and Poli, B. M. 2007. Effect of high-level fish meal replacement by plant proteins in gilthead sea bream (Sparus aurata) on growth and body/fillet quality traits. Aquac. Nutr., 13: 361-372. https://doi.org/10.1111/j.13652095.2007.00485.x.

Erlanger, B. F., Kokowsky, N. and Cohen, W. 1961. The preparation and properties of two new chromogenic substrates of trypsin. Arch. Biochem. Biophy., 95: 271-278. doi: 10.1016/0003-9861(61)90145-x.

Espe, M., Lemme, A., Petri, A. and El-Mowafi, A. 2006. Can Atlantic salmon (Salmo salar) grow on diets devoid of fish meal? Aquaculture, 255: 255-262. DOI:10.1016/j. aquaculture.2005.12.030.

Eusebio, P. S. and Coloso, R. M. 2002. Proteolytic enzyme activity of juvenile Asian seabass, Lates calcarifer (Bloch), is increased with protein intake. Aquac. Res., 33: 569-574. DOI:10.1046/j.1365-2109.2002.00682.x.

Finlayson, A. J. 1964 The compositions of some peptides produced by an enzymic hydrolysis of wheat gliadin. Can. J. Biochem., 42: 1133-1140. doi: 10.1139/o64-122.

Folk, J. and Schirmer, E. W. 1963. The porcine pancreatic carboxypeptidase A system I. Three forms of the active enzyme. J. Biol. Chem., 238: 3884-3894. DOI:10.1016/ S0021-9258(18)51803-2.

Folk, J. E., Piez, K. A., Carroll, W. R. and Gladner, J. A. 1960. Carboxypeptidase B IV. Purification and characterization of the porcine enzyme. J. Biol. Chem., 235: 2272-2277.

Fournier, V., Huelvan, C. and Desbruyeres, E. 2004. Incorporation of a mixture of plant feed stuffs as substitute for fish meal in diets of juvenile turbot (Psetta maxima). Aquaculture, 236: 451-465. DOI:10.1016/j.aquaculture.2004.01.035.

Glencross, B., Rutherford, N. and Jones, B. 2011. Evaluating options for fishmeal replacement in diets for juvenile barramundi (Lates calcarifer). Aquac. Nutr., 17: 722-732. https://doi.org/10.1111/j.1365-2095.2010.00834.x.

Gomes, E. F., Rema, P. and Kaushik, S. J. 1995. Replacement of fish meal by plant proteins in the diet of rainbow trout (Oncorhynchus mykiss): Digestibility and growth performance. Aquaculture, 130: 177-186.
Gonzalez-Felix, M. L., Davis, D. A., Rossi Jr. W. and PerezVelazquez, M. 2010. Evaluation of apparent digestibility coefficient of energy of various vegetable feed ingredients in Florida pompano, Trachinotus carolinus. Aquaculture, 310: 240-243. DOI:10.1016/j.aquaculture.2010.10.016.

Gonzelez-Felix, M. L., Gatlin III, D. M., Lawrence, A. L. and Perez-Velazquez, M. 2002. Effect of dietary phospholipid on essential fatty acid requirements and tissue lipid composition of Litopenaeus vannamei juveniles. Aquaculture, 207: 151-167. DOI:10.1016/S0044-8486(01) 00797-9.

Guroy, B., Sahin. I., Kayal. S., Mantoglu. S., Canan. B., Merrifield, D. L., Davies, S. J. and Guroy, D. 2013. Evaluation of feed utilisation and growth performance of juvenile striped catfish Pangasianodon hypophthalmus fed diets with varying inclusion levels of corn gluten meal. Aquac. Nutr., 19: 258-266.

Hummel, B. C. 1959. A modified spectrophotometric determination of chymotrypsin, trypsin, and thrombin. Can. J. Biochem. Physiol., 37: 1393-1399.

Izquierdo, M. S., Obach, A., Arantzamendi, L., Montero, D. and Robaina, L. 2003. Dietary lipid sources for sea bream and seabass: growth performance, tissue composition and flesh quality. Aquac. Nutr., 9: 397-407. https://doi.org/10.1046/ j.1365-2095.2003.00270.x

Jalili, R., Noori, F. and Agh, N. 2012. Effects of dietary protein source on growth performance, feed utilisation and digestive enzyme activity in rainbow trout (Oncorhynchus mykiss). J. Appl. Biol. Sci., 6: 61-68.

Jannathulla, R., Rajaram, V., Kalanjiam, R., Ambasankar, K., Muralidhar, M. and Dayal, J. S. 2019b. Fishmeal availability in the scenarios of climate change: Inevitability of fishmeal replacement in aquafeeds and approaches for the utilization of plant protein sources. Aquac. Res., 50: 3493-3506. https://doi.org/10.1111/are.14324.

Jannathulla, R., Dayal, J. S., Ambasankar, K., Eugine, A. C. and Muralidhar, M. 2018a. Fungus, Aspergillus niger, fermented groundnut oil cake as a fishmeal alternative in the diet of Penaeus vannamei. Aquac. Res., 49: 2891-2902.

Jannathulla, R., Syama Dayal, J., Ambasankar, K. and Muralidhar, M. 2018b. Effect of Aspergillus niger fermented soybean meal and sunflower oil cake on growth, carcass composition and haemolymph indices in Penaeus vannamei Boone, 1931. Aquaculture, 486: 1-8.

Jannathulla, R., Dayal, J. S., Vasanthakumar, D., Ambasankar, K. and Muralidhar, M. 2017a. Effect of fermentation methods on amino acids, fiber fractions and anti-nutritional factors in different plant protein sources and essential amino acid index for Penaeus vannamei Boone, 1931. Indian J. Fish., 64: 40-47.

Jannathulla, R., Dayal, J. S., Ambasankar, K., Khan, H. I., Madhubabu, E. P. and Muralidhar, M. 2017b. Effect of protein solubility of soybean meal on growth, digestibility and nutrient utilization in Penaeus vannamei. Aquac. Int., 25: 1693-1706. 
Jannathulla, R., Dayal, J. S., Vasanthakumar, D., Ambasankar, K., Panigrahi, A. and Muralidhar, M. 2019a. Apparent digestibility coefficients of fungal fermented plant proteins in two different penaeid shrimps - A comparative study. Aquac. Res., 50: 1491-1500.

Kaushik, S. J., Coves, D., Dutto, G. and Blanc, D. 2004. Almost total replacement of fish meal by plant protein sources in the diet of a marine teleost, the European seabass, Dicentrarchus labrax. Aquaculture, 230: 391-404. DOI: 10. 1016/s0044-8486(03)00422-8.

Khan, H. I., Dayal, J. S., Ambasankar, K., Madhubabu, E. P., Jannathulla, R. and Rajaram, V. 2018. Enhancing the dietary value of palm oil in the presence of lysolecithin in tiger shrimp, Penaeus monodon. Aquac. Int., 26: 509-522.

Khan, I. 2013. Studies on the fishmeal and fish oil replacement in the presence of lysolecithin in the diet of tiger shrimp, Penaeus monodon. Ph. D. dissertation, University of Madras, Chennai, India.

Kissil, G. W. and Lupatsch, I. 2004. Successful replacement of fishmeal by plant proteins in diets for the gilthead seabream, Sparus aurata L. Isr. J. Aquac. Bamidgeh, 56: 188-199.

Krogdahl, A., Bakke-McKellep, A. M. and Baeverfjord, G. 2003. Effects of graded levels of standard soybean meal on intestinal structure, mucosal enzyme activities, and pancreatic response in Atlantic salmon (Salmo salar L.). Aquac. Nutr., 9: 361-371. https://doi.org/10.1046/j.13652095.2003.00264.x.

Lin, S. and Luo, L. 2011. Effects of different levels of soybean meal inclusion in replacement for fish meal on growth, digestive enzymes and transaminase activities in practical diets for juvenile tilapia, Oreochromis niloticus $\times$ O. aureus. Anim. Feed Sci. Technol., 168: 80-87. https://doi.org/10. 1016/j.anifeedsci.2011.03.012.

Lowry, O. H., Rosebrough, N. J., Farr, A. L. and Randall, R. J. 1951. Protein measurement with the Folin phenol reagent. J. Biol. Chem., 193: 265-275. https://doi.org/10.1016/S00 21-9258(19)52451-6.

Madhubabu, E. P. 2019. Comparative study in relation to dietary formulations to digestive enzymes on brackishwater fishes with different food habits. Ph. D. dissertation, University of Madras, Chennai, India.

Messina, M., Piccolo, G., Tulli, F., Messina, C. M., Cardinaletti, G. and Tibaldi, E. 2013. Lipid composition and metabolism of European seabass (Dicentrarchus labrax L.) fed diets containing wheat gluten and legume meals as substitutes for fish meal. Aquaculture, 376: 6-14. https://doi. org/10.1016/j.aquaculture.2012.11.005.

Metcalfe, L. D., Schimitz, A. A. and Pelka, J. R. 1966. Rapid preparation of fatty acids esters from lipids for gas chromatographic analysis. Anal. Chem., 38: 524-535.

Montero, D., Robaina, L., Caballero, M. J., Gines. R. and Izquierdo, M. S. 2005. Growth, feed utilisation and flesh quality of European seabass (Dicentrarchus labrax) fed diets containing vegetable oils: A time-course study on the effect of a refeeding period with a $100 \%$ fish oil diet. Aquaculture, 248: 121-134. doi:10.1016/j. aquaculture.2005.03.003.

Nandakumar, S., Ambasankar, K., Ali, S. S., Syamadayal, J. and Vasagam, K. 2017. Replacement of fish meal with corn gluten meal in feeds for Asian seabass (Lates calcarifer). Aquac. Int., 25: 1495-1505. DOI 10.1007/s10499-0170133-2.

Nandakumar, S., Ambasankar, K., Dayal, J. S., Raman, C. and Ali, S. R. 2013. Fish meal replacement with chicken waste meal in Asian seabass (Lates calcarifer) feeds. Indian J. Fish., 60: 109-114.

Paleari, A., Beretta, G., Grimaldi, P. and Vaini, F. 1997. Composition of muscle tissue of farmed sturgeon with particular reference to lipidic content. J. Appl. Ichthyol., 13: 63-66.

Plaipetch, P. and Yakupitiyage, A. 2012. Use of yeast-fermented canola meal to replace fishmeal in the diet of Asian seabass Lates calcarifer (Bloch, 1790). J. Aquac. Res. Dev., 3: 1-5. DOI:10.4172/2155-9546.1000125.

Pratoomyot, J., Bendiksen, E. A., Bell, J. G. and Tocher, D. R. 2010. Effects of increasing replacement of dietary fishmeal with plant protein sources on growth performance and body lipid composition of Atlantic salmon (Salmo salar L.). Aquaculture, 305: 124-132. doi:10.1016/j. aquaculture.2010.04.019.

Sanchez-Lozano, N. B., Martinez-Llorens, S., Tomas-Vidal, A. and Cerda, M. J. 2011 Amino acid retention of gilthead seabream (Sparus aurata, L.) fed with pea protein concentrate. Aquac. Nutr., 17: 604-614.

Sastry, C. S. P. and Tammuru, M. K. 1985. Spectrophotometric determination of tryptophan in protein. J. Food Sci. Technol., 22: 146-147.

Tantikitti, C., Sangpong, W. and Chiavareesajja, S. 2005. Effects of defatted soybean protein levels on growth performance and nitrogen and phosphorus excretion in Asian seabass (Lates calcarifer). Aquaculture, 248: 41-50. https://doi. org/10.1016/j.aquaculture.2005.04.027.

Tomas-Vidal, A., Martinez-Llorens, S., Jambrina, C., de Saja Gonzalez, R. and Jover Cerda, M. 2011. Effects of dietary soybean meal on growth, nutritive efficiency and body composition of cultured tench (Tinca tinca). J. Appl. Ichthyol., 27: 892-896.

Tomas, A., Martinez-Llorens, S. and Jover, M. 2009. The effect of dietary soybean meal on growth, nutrient utilization efficiency and digestibility of juvenile common dentex, Dentex dentex (Actinopterygii: Perciformes: Sparidae). Acta Ichthyologica et Piscatoria, 39: 19-25. DOI:10.3750/ AIP2009.39.1.04.

USDA 2020. United States Department of Agriculture. https:// www.indexmundi.com/agriculture/?commodity=fish-meal (Accessed 30 September 2021). 
Walter, K. and Schutt, C. 1974. Alkaline phosphatase in serum: Continuous assay. Methods of enzymatic analysis. Academic Press, Massachusetts USA, p. 860-864.

Winkler, U. K. and Stuckmann, M. A. 1979. Glycogen, hyaluronate and some other polysaccharides greatly enhance the formation of exolipase by Serratia marcescens.
J. Bacteriol., 138: 663-670. doi: 10.1128/jb.138.3.663670.1979

Yu, D. H., Gong, S. Y., Yuan, Y. C. and Lin, Y. C. 2013. Effects of replacing fish meal with soybean meal on growth, body composition and digestive enzyme activities of juvenile Chinese sucker, Myxocyprinus asiaticus. Aquac. Nutr., 19: 84-90. 